\title{
Reaction and Performance of Some Sesame Genotypes for Resistance to Macrophomina phaseolina, the Incitant of Charcoal Rot Disease
}

\author{
Ismail M.A. Bedawy and Moustafa H.A. Moharm ${ }^{2}$
}

\begin{abstract}
Charcoal rot caused by Macrophomina phaseolina, is a destructive disease of sesame crop cultivated in Egypt. Eighty six sesame genotypes (Sesamum indicum L.) were used for evaluating disease resistance, in two successive summer seasons 2017 and 2018, in the field. Results obtained showed that highly significant variations were found between sesame genotypes tested in both seasons for disease infection percentage (DI \%) and seed yield (SY). In season 2017, only 14 sesame lines No. 33, 3, 15, 64, 40, 63, $14,39,4,16,13,80,58$ and 79 , were classified as a moderately resistant (MR). These lines exhibited lower DI\% of 13.33, 14.08, 14.44, 14.63, 15, 15.92, 16.67, 17.58, $18.33,18.33,18.51,19.08,20$ and $20 \%$, respectively. In the second season, traits of DI\% and SY showed the same trend and closest means. The MR lines group, of the first season manifested the same disease reaction from first season, with one exception of the line No. 16 it was moderately susceptible with DI\% increased to $25 \%$. The combined data of DI\% obtained from both seasons showed that 13, 21, 38 and 14 genotypes were MR, MS, S and HS, respectively.
\end{abstract}

Keywords: Sesame, charcoal rot, Macrophomina phaseolina, resistance, yield

\section{INTRODUCTION}

Sesame (Sesamum indicum L.) is one of the oldest oil crops cultivated in the world, it has been grown in the Near East and Africa for over five thousand years for oil, cooking and medicinal purposes. It is considered as one of crops that can be cultivated successfully, proving high yield under reclaimed soil conditions in desert. In Egypt, it can be cultivated in various soil types of clay, sandy and reclaimed soils. The mean unit area of sesame productivity was $1406.3 \mathrm{~kg} / \mathrm{ha}$ estimated from 32 thousand ha (76.16 thousand feddan) of total cultivated area in Egypt, thus it came as the seventh country in worldwide production (FAOSTAT, 2016).

Sesame plants are attacked by several pathogens causing serious diseases as major damaging factors to sesame plants cultivated in the whole world with severe losses of 7 million tones yearly (Ara et al., 2017). Among the important diseases of sesame, charcoal rot
(CR) caused by the soil-borne fungus Macrophomina phaseolina (Tassi) Goid (MP) is considered the most destructive one and causes $5-100 \%$ yield loss in all sesame growing areas (Vyas, 1981; Meena et al., 2018). Recently, the worldwide yield losses of sesame due to infection by MP are $57 \%$ whereas about $5 \%$ or more yield losses were also observed in Egypt (Bashir et al., 2017). Initially, the fungus MP can infect the root and lower stem of seedling and cause damping-off. Later, it can also infect the developed plants till maturity stage and cause CR symptoms on most or whole sesame plant especially during hot and dry conditions, and reduce plant growth and productivity (Abawi and Corrales, 1989; Khaleifa, 2003; Shabana et al., 2014). It has known that the fungus MP survives as sclerotia formed in the crop residues and soil. Also, it has been reported that it is a seed-borne pathogen and such previous characteristics make it difficult to be controlled (Maiti et al., 1988). However, some agricultural practices such as soil solarization and application of systemic fungicides have been previously recommended to reduce its destructive affects (Mahdy et al., 2005). Regarding to the toxicity of fungicides and their harmful and diverse effects to the environment, therefore various studies on $\mathrm{CR}$ disease of sesame discussed the different biological methods for disease control, i.e. using biocontrol agents such as bacteria and fungi (Abdul Sattar et al., 2006), plant extracts by seed soaking (Ahmed et al., 2010) and cultivating resistant varieties/genotypes were also recommended (Pereira et al., 1996; Gaber et al., 1998; Thiyagu et al., 2007). However, host plant resistance it remains the best strategy for disease control. Therefore, selection for new sesame genotypes resistant to MP is more useful, sustainable and safe approach to control $\mathrm{CR}$ disease and reduce the yield loss (Mahdy et al., 2005; Thiyagu et al., 2007; El-Bramawy and Abdul Wahid, 2006), although it needs more time (Bedigian, 2006). The current research was planned to study the performance of some sesame genotypes under the artificial infestation of soil with MP in field for evaluating the resistance to $\mathrm{CR}$ disease through

DOI: 10.21608/asejaiqjsae.2019.26294

${ }^{1 *}$ Agronomy Dept., ${ }^{2}$ Plant Pathology Dept. Fac. Agric. Sohag Univ.

Sohag, Egypt

*Corresponding author: ismail_bedawy@yahoo.com; Tel. 01003911668;

Fax. 0932287558; New Campus at El-Kawamel, Sohag, Egypt, P.O. 82755

Received January 3, 2019, Accepted January 28, 2019 
characterizing new resistant lines and improving yield of sesame.

\section{MATERIALS AND METHODS}

\section{Isolation and identification of the causal pathogen of sesame $C R$ disease}

Samples of diseased plants of sesame local cultivars showing CR symptoms were collected from sesame fields in different regions of Sohag Governorate, Egypt during 2015 growing season. Infected root and steam of each plant sample were washed thoroughly with tap water, cut into small segments (approx. 0.5-1.0 cm), surface sterilized by immersing in $1 \%$ sodium hypochlorite solution for $2 \mathrm{~min}$. Then segments were immediately rinsed for 3 times with sterile water. Disinfected segments were dried between two folds of sterilized filter papers, placed onto Petri dishes containing potato dextrose agar (PDA) medium supplemented with $400 \mathrm{mg}$ streptomycin sulphate per liter of medium. Plates were then incubated at $25 \pm 5^{\circ} \mathrm{C}$ for 5 days, during incubation plates were examined daily. The fungal growth around the segments was purified by hyphal tip technique following sub-culturing onto a fresh prepared medium at the same favorable conditions until pure colonies were formed. Then isolates were identified according the cultural and morphological characteristics described by Domsch et al. (1980) and Sutton (1980). Pure cultures of all identified isolates were maintained at $5^{\circ} \mathrm{C}$ on slopes of PDA medium for further studies.

\section{Pathogenicity tests}

The pathogenic capability of all isolates to cause CR disease was investigated on sesame Giza-32 cultivar under open greenhouse in 2015 summer growing season. Inoculum of each tested fungal isolate was prepared by placing two disks (0.6 in diameter) taken from 7-day-old fungal culture on autoclaved sorghum and washed sand medium ( $3: 1$, respectively) in glass bottles tightly closed with cotton plugs. Bottles were then incubated at $25 \pm 5^{\circ} \mathrm{C}$ for 20 days. Formalin-sterilized pots $(30 \mathrm{~cm}$ diameter) each was filled with autoclaved loam soil (7.0 $\mathrm{kg}$ of each), infested with $70 \mathrm{~g}$ inocula of each tested isolate and then slightly irrigated every other day for a week. Pots treated with the equal amount of sorghum and sand medium and free from fungal inocula served as control. Seeds were disinfected by dipping in $2 \%$ sodium hypochlorite solution for $3 \mathrm{~min}$, rinsed 3 times in sterile water for $5 \mathrm{~min}$ and then sown at the rate 10 seeds per each pot. Three pots as replicates of each tested fungal isolate were used in a completely randomized design. Pots were checked daily and irrigated when necessary. During growth and till plant maturity, symptoms of CR disease were noted and the infected plants were counted for each genotype in the replicate. Then the percentage of $\mathrm{CR}$ disease infection was calculated according to Bedawy (2004) as follow:

\section{Disease infection (DI) $\%=$ the number of infected plants/ total number of plants in the row $\times 100$ \\ Assessment of sesame genotypes to $C R$ resistance and yield losses in filed experiments}

Totally 86 genotypes of sesame were used in this study. They consist of 80 sesame lines, the parents of these lines were two introduced No. 153515 and No. 158071 from Venezuela and China, respectively, 'Giza25' and 'Giza-32' (Mahdy et al., 2005) and two sesame check cultivars 'Shandaweil-3' and 'Toshka-1'.

Two successful field trials were conducted in summer seasons 2017 and 2018 at the El-Kawther Experimental Farm, Faculty of Agriculture, Sohag University, Sohag, Egypt. Both sown date was $15^{\text {th }}$ May. In each trail, the seeds of each sesame line tested were sterilized as mentioned before and sown in hills on rows of plots in a randomized complete block design of three replications. Each row is $4 \mathrm{~m}$ long with $60 \mathrm{~cm}$ within rows and $20 \mathrm{~cm}$ between hills within rows. Each genotype was represented by one row in each replication. For plant inoculation, inoculum amount (approx. 40g) of isolate MP2 was added in hills with sesame seeds at same time of sowing and covered with soil (Mahdy et al., 2005). Following full emergence, the growing seedlings were thinned to two per hill in each row and all culture practices recommended for sesame production were carefully applied. During growth and till plant maturity, the percentage of DI was calculated as mentioned before. Levels of resistant for tested genotypes were scored following the scale of disease rating described by Thiyagu et al. (2007) and presented in Table 1. The other trait was seed yield per plant (SY) that was measured as a mean of seed yield from 10 random plants for each genotype in the three replicates. The yield loss for each genotype was determined by using data of SY obtained from another experiment which conducted at normal field conditions for the same genotypes (Bedawy and Mohamed 2018) as follow:

Yield losses $\%=100$ - (seed yield under infection/ seed yield at normal condition) $\times 100$.

Table 1. The disease scale used for evaluation of disease resistance in sesame lines.

\begin{tabular}{ll}
\hline Infection \% & Category \\
\hline $1-10$ & Resistant (R) \\
$11-20$ & Moderately Resistant (MR) \\
$21-30$ & Moderately Susceptible (MS) \\
$31-50$ & Susceptible (S) \\
$51-100$ & Highly Susceptible (HS) \\
\hline
\end{tabular}




\section{Statistical analysis}

The studied traits analyzed by using SAS program (SAS ver. 9.2, SAS Institute 2008). Comparing of means for each trait done by used the revised LSD (Petersen, 1985). Pearson correlation coefficient was calculated among studied traits in two years.

\section{RESULTS AND DISCUSSION}

Isolation from diseased plants showing $\mathrm{CR}$ symptoms collected from different regions of Sohag governorate resulted in 6 fungal isolates. The obtained isolates were identified as Macrophomina phaseolina (Tassi) Goid according the cultural and morphological characteristics described by Domsch et al. (1980) and Sutton (1980). Data of pathogenicity tests in Table (2) revealed that all obtained isolates of MP were pathogenic to sesame cultivar Giza-32, where they showed the same ideal CR symptoms on infected plants. Among all 6 isolates of MP obtained, only MP2 isolate was found to be highly pathogenic ones $(56.57 \%)$. While, MP5 was a weak isolate and caused $30 \%$ of disease infection. Results obtained were similar and in agreement with those reported by (Ahmed et al., 2010; Bashir et al., 2017).

In this study, the highly pathogenic isolate MP2 was used for inoculation sesame plants in field trails during 2017 and 2018 seasons in performance tests of a set of sesame genotypes evaluated for resistance to $\mathrm{CR}$ disease. Results showed that the analysis of variance for studied traits disease infection percentage (DI \%) and seed yield (SY) per plant revealed highly significant differences between genotypes under study in both seasons (Table 3). The trait of DI\% means varied from 13.33 to $66.67 \%$ in first season (Table 4). From the results obtained of the genotypes reactions to MP infection in the first season, only 14 sesame lines No., $33,3,15,64,40,63,14,39,4,16,13,80,58$ and 79 were classified as a moderately resistant (MR) and they exhibited lower means of DI\% 13.33, 14.08, 14.44, $14.63,15,15.92,16.67,17.58,18.33,18.33,18.51$,
$19.08,20$ and $20 \%$, respectively. On the other hand, 15 lines and the check cultivar "Toshka1" were moderately susceptible (MS). Moreover, the rest of tested genotypes varied in their reactions. Thiyagu et al., (2007) reported three resistant genotypes among fifteen parents and their F1's exhibiting 9.11, 8.34 and 7.92 DI\% and all crosses were varied from susceptible to highly susceptible to CR disease. In another study, the reaction of 24 F6 sesame lines and their parents for $\mathrm{CR}$ infection was three resistant lines $(\mathrm{C} 3.8, \mathrm{C} 6.3, \mathrm{C} 1.10)$ and one resistant parent, however, other three lines (C6.12, C6.11 and C9.6) were the highly susceptible and five from the six parents were moderately to highly susceptible (Shabana et al., 2014). The MR lines group had different values for trait SY, all values exceeded $14.50 \mathrm{~g}$, the SY means for the MR lines were 14.74, 14.90, 14.92, 14.94, 15.64, $16.14,16.18,16.19,16.70,17.03,17.18,17.22,17.23$ and 17.77 for lines number $15,33,13,14,16,58,3,80$, $4,64,79,40,63$ and 39, respectively. In case of these MR lines, the high seed yield (14.74-17.77 $\mathrm{g} / \mathrm{plant}$ ) is positively correlated with the relatively high resistance (less than 20 DI \%) and breaking the negative correlation between both traits (El-Bramawy and Abdul Wahid, 2006), therefore these lines have a preference to improve resistance and yield together. Over all 86 sesame genotypes the SY trait means in first season had a range of $9.65-17.77 \mathrm{~g} / \mathrm{plant}$. The losing in the seed yield due to infection by MP for genotypes varied from $0.14-37.31 \%$ in 61 genotypes tested. Moreover, 25 tested lines had no yield losses included the MR lines.

In the second season, traits of DI\% and SY showed the same trend and closest means. DI\% had a wide range of means and varied from 11.67 to $63.33 \%$. The MR lines group included 13 lines were the same from first season group with one exception, the line number 16 that left this MR group with DI\% mean increased to $25 \%$. Seed yield per plant trait ranged from 10.09 to $18.20 \mathrm{~g}$. Regarding to yield loss in this season, it varied from 0.22 to $33.98 \%$ in 59 sesame genotypes. Moreover, 27 tested lines recorded no yield loss.

Table 2. Pathogenicity test of M. phaseolina isolates on sesame Giza-32 cultivar performed under open greenhouse in growing season, 2015.

\begin{tabular}{ccccc}
\hline & & Isolate & Code & \multirow{2}{*}{ Disease infection \% } \\
\cline { 1 - 4 } No. & Source & Cultivar & MP1 & 53.33 \\
\hline 1 & El-kawther & Giza-32 & MP2 & 56.57 \\
2 & Sakolta & Giza-32 & MP3 & 36.67 \\
3 & Tema & Shandweil-3 & MP4 & 40.00 \\
4 & Sakolta & Shandweil-3 & MP5 & 30.00 \\
5 & Tema & Giza-32 & MP6 & 46.67 \\
6 & Gerga & Giza-32 & & 2.27 \\
\hline L.S.D. $\mathbf{0 . 0 5}$ & & & & \\
\hline
\end{tabular}


Table 3. Analysis of variance means and ranges for studied traits in two seasons 2017 and 2018 under artificial infection by M. phaseolina fungus.

\begin{tabular}{lccccc}
\hline \multicolumn{1}{r}{ Item } & \multicolumn{2}{c}{ Disease infection \% } & Seed yield g/ plant & Disease infection \% & Seed yield g/ plant \\
\hline S.O.V & DF & \multicolumn{2}{c}{ MS first season } & \multicolumn{2}{c}{ MS second season } \\
\hline Replication & 2 & 2.08 & 0.304 & 32.17 & 1.53 \\
Genotypes & 85 & $555.25^{* *}$ & $11.88^{* *}$ & $551.31^{* *}$ & $12.56^{* *}$ \\
Error & 170 & 19.68 & 0.571 & 19.89 & 0.582 \\
Mean & & 36.54 & 13.55 & 35.58 & 13.88 \\
Range & & $13.33-66.67$ & $9.65-17.77$ & $11.67-63.33$ & $10.09-18.20$ \\
\hline
\end{tabular}

MS: mean square, DF: degrees of freedom and ** highly significant.

Table 4. Sesame genotypes means for studied traits under field infection with $M$. phaseolina in the first and the second seasons, 2017, 2018 and combined.

\begin{tabular}{|c|c|c|c|c|c|c|c|c|c|c|c|}
\hline \multirow{2}{*}{ Line numbers } & \multicolumn{4}{|c|}{ Season 2017} & \multicolumn{4}{|c|}{ Season 2018} & \multicolumn{3}{|c|}{ Combined means } \\
\hline & DI\% & SY (g) & YL \% & $\mathbf{R}$ & DI\% & SY (g) & YL \% & $\mathbf{R}$ & DI\% & SY (g) & $\mathbf{R}$ \\
\hline 1 & 27.78 & 12.43 & 6.09 & MS & 29.07 & 11.47 & 11.74 & MS & 28.43 & 11.95 & MS \\
\hline 2 & 27.75 & 13.22 & 5.53 & MS & 29.25 & 13.50 & 11.67 & MS & 28.50 & 13.36 & MS \\
\hline 3 & 14.08 & 16.18 & 1.76 & MR & 14.92 & 16.03 & 1.88 & MR & 14.50 & 16.11 & MR \\
\hline 4 & 18.33 & 16.70 & 0.00 & MR & 16.67 & 16.12 & 0.00 & MR & 17.50 & 16.41 & MR \\
\hline 5 & 30.00 & 15.70 & 5.46 & MS & 28.33 & 15.08 & 10.15 & MS & 29.17 & 15.39 & MS \\
\hline 6 & 23.33 & 16.58 & 9.47 & MS & 28.33 & 16.96 & 10.44 & MS & 25.83 & 16.77 & MS \\
\hline 7 & 37.96 & 12.44 & 8.44 & $\mathrm{~S}$ & 35.00 & 11.59 & 11.97 & $\mathrm{~S}$ & 36.48 & 12.02 & $\mathrm{~S}$ \\
\hline 8 & 41.67 & 12.45 & 12.45 & $\mathrm{~S}$ & 40.00 & 12.51 & 16.47 & $\mathrm{~S}$ & 40.83 & 12.48 & $\mathrm{~S}$ \\
\hline 9 & 31.89 & 14.25 & 7.55 & $\mathrm{~S}$ & 28.33 & 14.42 & 7.70 & MS & 30.11 & 14.33 & MS \\
\hline 10 & 36.67 & 14.09 & 7.08 & $\mathrm{~S}$ & 30.92 & 14.45 & 10.32 & MS & 33.80 & 14.27 & $\mathrm{~S}$ \\
\hline 11 & 22.92 & 14.97 & 10.31 & MS & 23.33 & 15.66 & 5.53 & MS & 23.13 & 15.32 & MS \\
\hline 12 & 25.74 & 15.29 & 8.72 & MS & 22.33 & 16.54 & 5.93 & MS & 24.04 & 15.91 & MS \\
\hline 13 & 18.51 & 14.92 & 0.00 & MR & 14.08 & 16.17 & 0.00 & MR & 16.30 & 15.54 & MR \\
\hline 14 & 16.67 & 14.94 & 0.00 & MR & 15.75 & 15.98 & 0.00 & MR & 16.21 & 15.46 & MR \\
\hline 15 & 14.44 & 14.74 & 0.00 & MR & 15.92 & 15.91 & 0.00 & MR & 15.18 & 15.32 & MR \\
\hline 16 & 18.33 & 15.64 & 0.00 & MR & 25.00 & 15.77 & 0.00 & MS & 21.67 & 15.71 & MS \\
\hline 17 & 54.45 & 10.50 & 6.47 & HS & 55.00 & 12.01 & 0.00 & HS & 54.72 & 11.26 & HS \\
\hline 18 & 51.85 & 11.10 & 11.81 & HS & 53.33 & 12.34 & 0.22 & HS & 52.59 & 11.72 & HS \\
\hline 19 & 38.33 & 9.65 & 23.72 & $\mathrm{~S}$ & 36.67 & 10.09 & 21.82 & $\mathrm{~S}$ & 37.50 & 9.87 & $\mathrm{~S}$ \\
\hline 20 & 41.67 & 11.39 & 8.44 & $\mathrm{~S}$ & 40.00 & 11.79 & 9.91 & $\mathrm{~S}$ & 40.83 & 11.59 & $\mathrm{~S}$ \\
\hline 21 & 55.00 & 14.59 & 8.28 & HS & 61.67 & 15.04 & 11.29 & HS & 58.33 & 14.82 & HS \\
\hline 22 & 31.25 & 14.96 & 4.73 & $\mathrm{~S}$ & 28.33 & 16.28 & 0.45 & MS & 29.79 & 15.62 & MS \\
\hline 23 & 41.67 & 12.92 & 10.46 & S & 40.00 & 12.90 & 10.95 & $\mathrm{~S}$ & 40.83 & 12.91 & $\mathrm{~S}$ \\
\hline 24 & 25.00 & 14.98 & 0.00 & MS & 28.33 & 14.88 & 0.00 & MS & 26.67 & 14.93 & MS \\
\hline 25 & 53.33 & 12.83 & 0.00 & HS & 50.00 & 12.57 & 0.00 & $\mathrm{~S}$ & 51.67 & 12.70 & HS \\
\hline 26 & 58.33 & 10.20 & 16.56 & HS & 60.00 & 11.30 & 6.04 & HS & 59.17 & 10.75 & HS \\
\hline 27 & 61.67 & 11.05 & 18.09 & HS & 61.67 & 10.41 & 26.35 & HS & 61.67 & 10.73 & HS \\
\hline 28 & 55.00 & 12.45 & 13.62 & HS & 48.33 & 12.34 & 13.43 & $\mathrm{~S}$ & 51.67 & 12.39 & $\mathrm{~S}$ \\
\hline 29 & 43.78 & 10.89 & 37.31 & $\mathrm{~S}$ & 39.11 & 11.63 & 33.98 & S & 41.44 & 11.26 & S \\
\hline 30 & 41.67 & 11.67 & 31.33 & S & 46.67 & 12.50 & 28.22 & $\mathrm{~S}$ & 44.17 & 12.08 & S \\
\hline 31 & 61.67 & 14.39 & 0.00 & HS & 55.00 & 15.39 & 0.00 & HS & 58.33 & 14.89 & HS \\
\hline 32 & 36.67 & 14.18 & 0.00 & $\mathrm{~S}$ & 35.00 & 14.57 & 0.00 & $\mathrm{~S}$ & 35.83 & 14.38 & $\mathrm{~S}$ \\
\hline 33 & 13.33 & 14.90 & 11.97 & MR & 11.67 & 15.22 & 15.63 & MR & 12.50 & 15.06 & MR \\
\hline 34 & 28.33 & 12.67 & 25.14 & MS & 25.00 & 13.14 & 22.61 & MS & 26.67 & 12.90 & MS \\
\hline 35 & 25.09 & 11.19 & 11.78 & MR & 23.33 & 12.02 & 6.82 & MS & 24.21 & 11.60 & MS \\
\hline 36 & 31.67 & 11.05 & 16.45 & MS & 30.00 & 10.64 & 13.33 & MS & 30.83 & 10.85 & MS \\
\hline 37 & 35.00 & 12.82 & 12.65 & MS & 41.67 & 12.97 & 11.81 & $\mathrm{~S}$ & 38.33 & 12.90 & $\mathrm{~S}$ \\
\hline 38 & 41.30 & 13.08 & 11.58 & MS & 45.00 & 13.32 & 15.64 & $\mathrm{~S}$ & 43.15 & 13.20 & $\mathrm{~S}$ \\
\hline
\end{tabular}


Table 4. Continued

\begin{tabular}{|c|c|c|c|c|c|c|c|c|c|c|c|}
\hline \multirow{2}{*}{ Line numbers } & \multicolumn{4}{|c|}{ Season 2017} & \multicolumn{4}{|c|}{ Season 2018} & \multicolumn{3}{|c|}{ Combined means } \\
\hline & DI\% & SY (g) & YL \% & $\mathbf{R}$ & DI\% & SY (g) & YL \% & $\mathbf{R}$ & DI\% & SY (g) & $\mathbf{R}$ \\
\hline 39 & 17.58 & 17.77 & 0.00 & MR & 14.08 & 17.87 & 0.00 & MR & 15.83 & 17.82 & MR \\
\hline 40 & 15.00 & 17.22 & 0.14 & MR & 14.22 & 17.64 & 0.00 & MR & 14.61 & 17.43 & MR \\
\hline 41 & 45.00 & 10.47 & 31.28 & $\mathrm{~S}$ & 41.67 & 11.07 & 25.48 & $\mathrm{~S}$ & 43.33 & 10.77 & $\mathrm{~S}$ \\
\hline 42 & 40.00 & 11.61 & 4.89 & $\mathrm{~S}$ & 48.33 & 11.74 & 9.87 & $\mathrm{~S}$ & 44.17 & 11.68 & $\mathrm{~S}$ \\
\hline 43 & 40.00 & 13.91 & 1.60 & $\mathrm{~S}$ & 38.33 & 13.38 & 9.82 & $\mathrm{~S}$ & 39.17 & 13.65 & $\mathrm{~S}$ \\
\hline 44 & 40.00 & 12.76 & 5.62 & $\mathrm{~S}$ & 36.67 & 12.18 & 15.86 & $\mathrm{~S}$ & 38.33 & 12.47 & $\mathrm{~S}$ \\
\hline 45 & 55.00 & 11.46 & 19.88 & HS & 56.11 & 11.70 & 20.11 & HS & 55.56 & 11.58 & HS \\
\hline 46 & 66.67 & 12.51 & 10.22 & HS & 61.67 & 12.86 & 12.14 & HS & 64.17 & 12.69 & HS \\
\hline 47 & 60.00 & 15.46 & 0.00 & HS & 58.33 & 15.70 & 0.00 & HS & 59.17 & 15.58 & HS \\
\hline 48 & 45.00 & 14.72 & 0.00 & $\mathrm{~S}$ & 40.75 & 14.96 & 0.00 & $\mathrm{~S}$ & 42.88 & 14.84 & $\mathrm{~S}$ \\
\hline 49 & 41.67 & 16.87 & 0.51 & S & 43.33 & 16.97 & 3.85 & S & 42.50 & 16.92 & S \\
\hline 50 & 48.33 & 16.89 & 0.00 & $\mathrm{~S}$ & 43.33 & 17.42 & 0.00 & $\mathrm{~S}$ & 45.83 & 17.16 & $\mathrm{~S}$ \\
\hline 51 & 38.33 & 13.70 & 0.00 & S & 43.33 & 14.07 & 0.00 & S & 40.83 & 13.89 & S \\
\hline 52 & 46.67 & 13.62 & 0.00 & S & 45.75 & 14.95 & 0.00 & S & 46.21 & 14.28 & S \\
\hline 53 & 32.78 & 12.66 & 20.51 & S & 31.11 & 12.54 & 25.58 & S & 31.95 & 12.60 & S \\
\hline 54 & 36.67 & 12.45 & 24.93 & S & 31.67 & 13.44 & 21.77 & $\mathrm{~S}$ & 34.17 & 12.95 & S \\
\hline 55 & 65.00 & 14.10 & 0.00 & HS & 63.33 & 15.12 & 0.00 & HS & 64.17 & 14.61 & HS \\
\hline 56 & 61.67 & 13.66 & 11.30 & HS & 60.00 & 14.19 & 9.29 & HS & 60.83 & 13.92 & HS \\
\hline 57 & 25.00 & 15.23 & 0.00 & MS & 21.67 & 15.69 & 0.00 & MS & 23.33 & 15.46 & MS \\
\hline 58 & 20.00 & 16.14 & 0.00 & MR & 17.42 & 17.04 & 0.00 & MR & 18.71 & 16.59 & MR \\
\hline 59 & 40.00 & 10.89 & 8.15 & $\mathrm{~S}$ & 33.33 & 12.02 & 0.28 & $\mathrm{~S}$ & 36.67 & 11.46 & $\mathrm{~S}$ \\
\hline 60 & 41.67 & 11.32 & 13.12 & $\mathrm{~S}$ & 37.42 & 11.19 & 15.57 & $\mathrm{~S}$ & 39.54 & 11.25 & $\mathrm{~S}$ \\
\hline 61 & 25.00 & 13.61 & 5.81 & MS & 23.33 & 12.71 & 12.22 & MS & 24.17 & 13.16 & MS \\
\hline 62 & 25.00 & 14.64 & 0.00 & MS & 23.33 & 14.41 & 0.00 & MS & 24.17 & 14.53 & MS \\
\hline 63 & 15.92 & 17.23 & 0.00 & MR & 16.67 & 18.20 & 0.00 & MR & 16.29 & 17.72 & MR \\
\hline 64 & 14.63 & 17.03 & 0.00 & MR & 16.66 & 17.15 & 0.00 & MR & 15.65 & 17.09 & MR \\
\hline 65 & 31.67 & 12.03 & 27.49 & $\mathrm{~S}$ & 32.78 & 12.02 & 29.02 & $\mathrm{~S}$ & 32.22 & 12.02 & $\mathrm{~S}$ \\
\hline 66 & 38.33 & 11.63 & 26.14 & S & 33.33 & 12.01 & 26.54 & $\mathrm{~S}$ & 35.83 & 11.82 & $\mathrm{~S}$ \\
\hline 67 & 27.50 & 13.55 & 21.99 & MS & 25.00 & 13.91 & 22.55 & MS & 26.25 & 13.73 & MS \\
\hline 68 & 26.67 & 13.89 & 20.02 & MS & 26.11 & 14.88 & 18.89 & MS & 26.39 & 14.39 & MS \\
\hline 69 & 31.67 & 15.28 & 2.01 & $\mathrm{~S}$ & 36.67 & 15.19 & 4.35 & $\mathrm{~S}$ & 34.17 & 15.23 & $\mathrm{~S}$ \\
\hline 70 & 38.33 & 16.16 & 0.00 & S & 35.00 & 16.44 & 0.00 & S & 36.67 & 16.30 & S \\
\hline 71 & 48.33 & 14.52 & 0.00 & $\mathrm{~S}$ & 46.67 & 14.30 & 0.00 & $\mathrm{~S}$ & 47.50 & 14.41 & $\mathrm{~S}$ \\
\hline 72 & 48.33 & 11.98 & 13.56 & S & 45.00 & 12.10 & 7.91 & S & 46.67 & 12.04 & S \\
\hline 73 & 40.00 & 12.94 & 18.54 & $\mathrm{~S}$ & 35.00 & 13.53 & 15.35 & S & 37.50 & 13.24 & S \\
\hline 74 & 41.67 & 12.25 & 16.87 & S & 45.00 & 12.59 & 19.09 & $\mathrm{~S}$ & 43.33 & 12.42 & S \\
\hline 75 & 44.63 & 13.21 & 16.53 & S & 43.33 & 13.17 & 15.31 & S & 43.98 & 13.19 & S \\
\hline 76 & 45.00 & 12.58 & 17.67 & $\mathrm{~S}$ & 40.00 & 12.57 & 24.97 & S & 42.50 & 12.57 & S \\
\hline 77 & 40.83 & 9.95 & 17.15 & S & 41.67 & 10.39 & 20.23 & S & 41.25 & 10.17 & S \\
\hline 78 & 37.92 & 11.15 & 7.70 & $\mathrm{~S}$ & 35.78 & 11.16 & 9.83 & $\mathrm{~S}$ & 36.85 & 11.16 & $\mathrm{~S}$ \\
\hline 79 & 20.00 & 17.18 & 0.00 & MR & 18.33 & 17.59 & 0.00 & MR & 19.17 & 17.38 & MR \\
\hline 80 & 19.08 & 16.19 & 0.00 & MR & 18.50 & 16.75 & 0.00 & MR & 18.79 & 16.47 & MR \\
\hline
\end{tabular}


Table 4. Continued

\begin{tabular}{cccccccccccc}
\hline \multirow{2}{*}{ Line numbers } & \multicolumn{4}{c}{ Season 2017 } & \multicolumn{4}{c}{ Season 2018 } & \multicolumn{3}{c}{ Combined means } \\
\cline { 2 - 13 } & DI\% & SY $(\mathbf{g})$ & YL \% & R & DI\% & SY (g) & YL \% & R & DI\% & SY (g) & R \\
\hline Intr. No. 153515 & 53.33 & 12.48 & 5.84 & HS & 51.67 & 12.61 & 2.45 & HS & 52.50 & 12.55 & HS \\
Intr. No. 158071 & 45.00 & 11.08 & 5.17 & S & 53.33 & 11.81 & 2.53 & HS & 49.17 & 11.45 & S \\
Giza25 & 25.00 & 12.58 & 2.98 & MS & 23.33 & 13.02 & 4.75 & MS & 24.17 & 12.80 & MS \\
Giza32 & 50.00 & 12.17 & 3.97 & S & 45.00 & 12.86 & 5.65 & S & 47.50 & 12.51 & S \\
Shandaweil3 & 31.67 & 13.47 & 0.52 & S & 29.24 & 13.67 & 6.58 & MS & 30.46 & 13.57 & MS \\
Toshka1 & 23.33 & 13.38 & 2.45 & MS & 24.44 & 13.68 & 7.44 & MS & 23.89 & 13.53 & MS \\
RLSD $_{.05}$ & 6.40 & 1.09 & & & 6.44 & 1.10 & & & 6.34 & 0.98 & \\
RLSD $_{.01}$ & 8.36 & 1.31 & & & 8.41 & 1.43 & & & 8.25 & 1.27 &
\end{tabular}

DI\%: Disease infection \%, SY: Seed yield/plant, R: Reaction to disease, YL\%: yield losses \%, RLSD .05, RLSD. 0.05 and 0.01 , respectively.

Generally, the combined DI\% means of the first and the second seasons showed that, 13, 21, 38 and 14 genotypes were MR, MS, S and HS, respectively. For the cultivars group the DI\% combined means exhibited that, 'Toshka1', 'Giza25' and 'Shandawiel3' were MS with DI\% values of $23.89,24.17$ and $30.46 \%$, respectively. The rest of cultivars group were $\mathrm{S}$ and HS in their reaction to MP infection.

On the basis of obtained results, the phenotypic correlation between DI\% and SY was negatively and highly significant with values -0.469 and -0.447 in the first and second season, respectively. Such correlation between DI\% and SY was similar to that reported by ElBramawy and Abdul Wahid (2006) who found that the correlation coefficient between SY/feddan and DI\% was -0.82 and -0.80 in F3 and F4 in the first year and -0.33 and -0.40 in the second year.

\section{CONCLUSION}

Based on the aforementioned obtained results it can be concluded that, the moderate resistant lines to $\mathrm{CR}$ disease of sesame should be used as promised resources of resistance in further breeding programs to $\mathrm{CR}$ disease.

\section{REFERENCES}

Abawi, G.S. and P. Corrales.1989.Charcoal rot screening procedure and virulence of Macrophomina phaseolina isolates on dry edible bean. Turrialba. 39: 200-207.

Abdul Sattar, M.H., A.M. Salem and A.A. Bayounes. 2006. Physical and biological control of charcoal root rot in sesame caused by Macrophomina phaseolina (Tassi) Goid. Arab J. Pl. Prot. 24: 37-40.

Ahmed, H. A. M., A. A. Abdel-Razik, M. H. A. Hassan and S. A. Khaled. 2010.Management of charcoal rot of sesame by seed soaking in medicinal plant extracts and hot water. Plant Pathol. J. 26(4): 372-379.
Ara, A., A. Akram, M. Ajmal, S. Akhund, B. G. Nayyar, W. Seerat, and S. M. Chaudhry. 2017. Histopathological studies of sesame (Sesamum indicum) seedlings infected with Fusarium oxysporum. Plant Pathology \& Quarantine. 7(1): 82-90.

Bashir, M. R., A. Mahmood, M. Sajid, M. A. Zeshan, M. Mohsan, Q. A. T. Khan, and F. A. Tahir. 2017.Exploitation of new chemistry fungicides against charcoal rot of sesame caused by Macrophomina phaseolina in Pakistan. Pak. J. Phytopathol. 29 (02): 257263.

Bedawy, I. M. A. 2004. Pedigree selection for wilt resistance in some sesame populations, Sesamum indicum L. M. Sc. Assiut University.

Bedawy, I. M. A. and N. E. Mohamed.2018. Phenotypic and genotypic variability in some sesame (Sesamum indicum L.) genotypes. Egyptian Journal of Agronomy. 40 (3): 193- 205.

Bedigian, D. 2006.Assessment of sesame and its wild relatives in Africa. In: Ghazanfar, S.A. and H. Beentje (Editors). African plants: Biodiversity, Ecology, Phytogeography and Taxonomy. Royal Botanic Gardens, Kew, United Kingdom.

Domsch, K. H., W. Gams and A. Traute-Heidi. 1980.Compendium of Soil Fungi. (Ed.) Academic Press. A Subbsidiary of Harcourt Brace Jovanovich, Publishers, London, pp 859.

EL-Bramawy, M. A. S. and O.A. Abdul Wahid. 2006. Field resistance of crosses of sesame (Sesamum indicum L.) to charcoal root rot caused by Macrophomina phaseolina (Tassi.) Goid. Plant Protect. Sci. 42: 66-72.

FAOSTAT.2016. Rome, Italy: Food and Agriculture Organization (FAO); Available from: http://www.fao.org/faostat/en/\#data/QC.

Gaber, M. R., N. A.Hussein, O. I. Saleh, and M. A. Khalil. 1998. Susceptibility of certain varieties and genotypes and control of wilt and root-rot diseases of sesame attributed to Fusarium oxysporium f.sp. sesami and Macrophomina phaseolina. Egyp. J. Microbiology. 33:403-428. 
Khaleifa, M. M. A. 2003.Pathological studies on charcoal rot disease of sesame. Ph.D. Thesis, Agron. Dept. Fac. of Agric., Moshtohor, Zagazig Univ., Benha, Branch, Egypt, $295 \mathrm{pp}$.

Mahdy, E. E., B. R. Bakheit, Motawea, M. M. and I. M. A. Bedawy. 2005. Pedigree selection for resistance to Sclerotium bataticola in three sesame populations. Assuit Journal of Agriculture Sciences 63(1): 57-72.

Maiti, S., M.R. Hegdeand S.B. Chattopadhyay. 1988. Handbook of Annual Oilseed Crops. Oxford and IBH Publ. Co. Pvt. Ltd., New Delhi.

Meena, B., P. Indiragandhi, and R. Ushakumari. 2018.Screening of sesame (Sesamum indicum L.) germplasm against major diseases. Journal of Pharmacognosy and Phytochemistry. SP1: 1466-1468.

Pereira, J., S. Gutierrez and L.J. Subero.1996. Behavior of 15 genotypes of Sesamum indicum L. against Macrophomina phaseolina (Tassi) Goid. Annales de Botanica Agricola 3: 33- 37.
Petersen, R.G. 1985. Design and analysis of experiments. Marcel Dekker, Inc., New York, USA.

SAS Institute. 2008.The SAS system for Windows, release 9.2.SAS Institute, Cary, N.C. USA.

Shabana, R., A.A. Abd El-Mohsen, M. M. A. Khalifa and A. A. Saber.2014. Quantification of resistance of F6 sesame elite lines against Charcoal-rot and Fusarium wilt diseases. Adv. Agric. Biol. 1 (3): 144-150.

Sutton, B.C. 1980.The Coelomycetes. Fungi Imperfect with Pycnidia, Acervuli and Stromata. Commonwealth Mycological Institute, Kew, Surrey, England, 696 pp.

Thiyagu, K., G. Kandasamy, N. Manivannan, V. Muralidharan and S.K. Manoranjitham. 2007.Identification of resistant genotypes to root rot disease (Macrophomina phaseolina) of sesame (Sesamum indicum L.). Agric. Sci. Digest. 27 (1): 34 - 37.

Vyas, S.C. 1981. Diseases in sesame in India and their control. Pesticides. 15: 10.

$$
\begin{aligned}
& \text { الملخص العربي } \\
& \text { اداء بعض التراكيب الوراثية للسمسم لمقاومة فطر ماكروفومينا فاصيولينا- المسبب المرضي لمرض لمربم } \\
& \text { العفن الفحمي } \\
& \text { إسماعيل محمود أحمد بديوي، مصطفي حمدان أحمد محرم } \\
& \text { - IN, T }-1 V, 0 \Lambda-17,7 V-10,9 Y-10-1 \leqslant, 7 T
\end{aligned}
$$

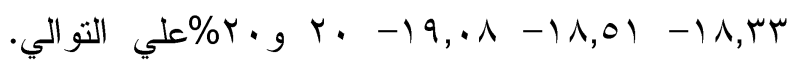

$$
\begin{aligned}
& \text { بينما كانت خمس عشر سلالة والصنف توشكي المعتلده } \\
& \text { الحساسية للاصابة. } \\
& \text { في العام الثاني لم تظهر النتائج اختلافات معنوية عن }
\end{aligned}
$$

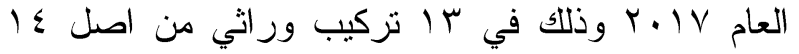

$$
\begin{aligned}
& \text { تركيب وراثي في حين أظهر تركيب ور اثي واحد رقم } 17
\end{aligned}
$$

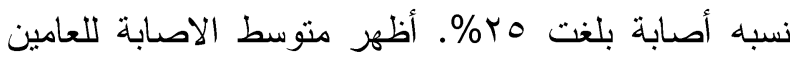

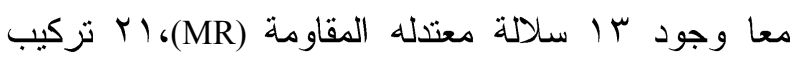

$$
\begin{aligned}
& \text { وراثي معتدله الحساسية (MS)، مب تركيب ور اثي حساس } \\
& \text { و ـ ا تركيب وراثي عالي الحساسية (HS) للاصابة } \\
& \text { بمرض العفن الفحمي. } \\
& \text { يعتبر العفن الفحمي مرض مدمر لمحصول السمسم في } \\
& \text { جمهورية مصر العربية. في هذه الدراسة تم تقييم أداء } 17 \\
& \text { تزكيب وراثي من السمسم ضد المسبب المرضى الفطر }
\end{aligned}
$$

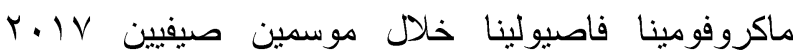

$$
\begin{aligned}
& \text { و 11 إب تحت ظروف العدوي الصناعية في الحقل. } \\
& \text { أظهرت النتائج وجود أختلافات معنوية بين التزاكيب } \\
& \text { الوراثية تحت الدراسة لصفتي النسبة المئوية للاصابة } \\
& \text { و المحصول في كلا العامين. }
\end{aligned}
$$

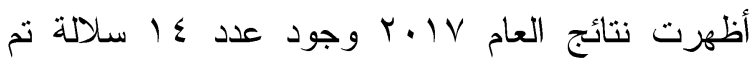

$$
\begin{aligned}
& \text { توصيفها معتدله المقاومة للمرض وهم السلالات أرقام: } \\
& \text { - } 17-\text { - } \\
& \text { rا - . - } \\
& \text { الاصابة بنسب مئوية: سr, سا- }
\end{aligned}
$$

